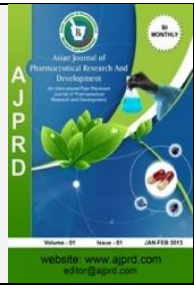

Open○ Access

\title{
Anti-Inflammation Activity of Virgin Coconut Oil In-Vitro Against Raw Cells 264.7
}

\author{
Amin $\mathbf{M}^{* 1}$, Silalahi $\mathbf{J}^{1}$, Harahap $\mathbf{U}^{2}$, Satria $\mathrm{D}^{3}$.
}

1Department of Chemistry, Faculty of Pharmacy, Universitas Sumatera Utara, Medan, Indonesia; ${ }^{2}$ Departemen of Pharmacology, Faculty of Pharmacy, Universitas Sumatera Utara, Medan, Indonesia; 32Departemen of Biology, Faculty of Pharmacy, Universitas Sumatera Utara, Medan, Indonesia

\begin{abstract}
A B S T R A C T
Objective:This study aimsto determine the anti-inflammation activity of pure coconut oil on Raw Cell 264.7 induced by LPS

Methods: The anti-inflammation activity test for Virgin Coconut Oil (VCO) was carried out by testing the expression of TNF- $\alpha$, IL-6, IL-1 $\beta$, iNOS, and COX-2 genes on RAW 264.7 cells induced by LPS by the method Reverse Transcription-Polymerase Chain Reaction (RT-PCR).

Results: The test results of iNOS, TNF- $\alpha$, IL-6, IL-1 $\beta$, and COX-2 gene expression from VCO on RAW 264.7 cells induced by lipopolysaccharide (LPS) decreased the value of VCO density. In iNOS expression, VCO density values $(0,90 \pm 0,015)$ showed significantly different effects with positive and negative controls $\mathrm{p}<0,05$, VCO IL- $1 \beta$ density values $(2,47 \pm 0,010)$ showed different effects. significant with normal control, positive control and negative control $\mathrm{p}<0,05$, TNF- $\alpha$ density value on $\operatorname{VCO}(0,91 \pm 0,010)$ showed significantly different effects from positive control and negative control $\mathrm{p}<0,05$, then the value IL-6 density at VCO $(1,23 \pm 0,015)$ showed significantly different effects from normal and positive controls $\mathrm{p}<0,05$, and COX-2 density values at VCO $(1,02 \pm 0,015)$ showed significantly different effects with normal and positive controls $\mathrm{p}<0,05$.

Conclusion: Based on the results of this study VCO on RAW 264.7 cells induced by LPS can inhibit the expression of TNF- $\alpha$, IL-6, IL-1 $\beta$, iNOS, and COX-2 genes so that VCO effectively has anti-inflammatory activity.
\end{abstract}

Keywords: VCO, Antiinflammation, RAW 264.7 Cells, Gene Expression, Lipopolysaccharides

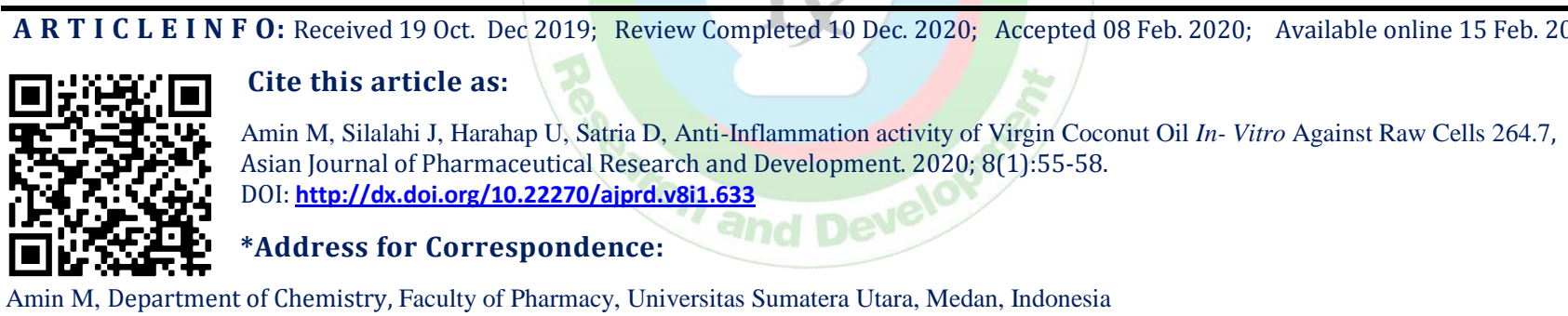

\section{INTRODUCTION}

I nflammation is the body's defense response to damage or infection due to foreign objects, such as bacteria, parasites and viruses. ${ }^{1,4}$ Inflammation functions to reduce, or localize (sekuster) either in damaging agents or damaged tissue, inflammation or inflammation can be triggered by various physical, chemical, or biological agents 2,9 .

Lipopolysaccharide (LPS) is the main component of gram-negative bacteria, which plays an important role in triggering inflammation. LPS causes macrophages to secrete molecules that increase the release of inflammatory mediators, as well as the release of cytokines that are mostly released from macrophages ${ }^{12}$. Anti-inflammatory is a term for agents or drugs that work against or suppress the inflammatory process, and antiinflammatory drugs commonly used are divided into two groups, namely steroid anti-inflammatory drugs and nonsteroidal anti-inflammatory drugs. But these drugs have many side effects that are harmful to the body, so we need natural anti-inflammatory drugs that are safe for the body such as $\mathrm{VCO}^{9}$.

Virgin coconut oil (VCO) contains phytosterols which can provide anti-inflammatory, analgesic and antipyretic effects ${ }^{3,8}$. VCO is a medium chain triglyceride, because it consists of medium chain fatty acids, VCO can be hydrolyzed faster and more complete than long chain triglycerides. Chain fatty acids are being hydrolyzed more rapidly by lipase enzymes in the mouth and in the stomach to produce monoacylglycerol and free fatty acids which are then quickly absorbed through the mucosa and through the portal veins that are transported directly to the liver, one of the tests carried out to determine the antiinflammatory activity of this VCO by testing gene expression on RAW 264.7 cells LIT-induced in vitro using RT-PCR ${ }^{5}$.

\section{MATERIALS AND METHODS}

Materials and Tools 
Autoclave (Hirayama), conical tube (Thermo Scientific), electrophoresis (BioRad), falcon tube (Thermo Scientific), Gel Doc (Syngene), $\mathrm{CO}_{2}$ incubator (Heraceus), Laminar Air Flow (Labconco), microscope inverted (Olympus), microplate reader (Bio Rad), micropipette (Eppendorf), microwave (Panasonic), nanovue plus (fisher scientific), neubauerhemocytometer (Hausser Scientific), electric balance (Vibra AJ), oven (Memmert), PCR (ProFlex, Applied Biosystems), centrifugator (Eppendorf), rotary evaporator (Stuart), vortex (IKA), 6-well plate (Iwaki), 96-wells plate (Iwaki). VCO (Palm Mustika®, Indonesia). RAW Cell 264.7, Dulbecco's Modified Eagle's Medium (DMEM) (Biowest) growth media, Fetal Bovine Serum (FBS) $10 \%$ (v/v) (Gibco), penicillin-streptomycin 2\% (v/v) (Gibco), Fungizone (FBS) Amphotericin B) (Sigma), $\mathrm{NaHCO}_{3}, \mathrm{NaNO}_{3}$ (Sigma). Dexamethasone (Harsen), $\quad 0.25 \% \quad$ Trypsin-EDTA (Gibco), Lipopolysaccharides (Sigma), MTT [3-(4,5dimethyltiazol-2-il)-2,5 diphenylethrazolium bromide) (Sigma), phosphate buffer saline (PBS) (Irvine Scientific), sodium dodecyl sulfate (SDS) in $0.1 \mathrm{~N} \mathrm{HCl}$, Total RNa kit (Geneaid), Tra-Ace Rever (Toyobo), wash buffer, DNase, water-free RNase, iNOS primer, IL-6 primer, TNF- $\alpha$ primer, IL-1 $\beta$ primer, COX-2 primer, GoTaq ${ }^{\circledR G}$ Green Master Mix (Promega), TBE (Vivantis), agarose (Promega), FluoroVue (Smobio), DNA ladder 100 bp (Smobio) .

\section{RESEARCH METHODS}

\section{RNA extraction}

Total RNA was isolated using an RNA isolation kit (Geneaid). RNA extraction is carried out by the stages of cell lysis, washing and elution of RNA ${ }^{6}$.

\section{a. Cell Lysis Stage}

RAW cells $264.7\left(5 \times 10^{5}\right.$ cells / well) that have been harvested are added $400 \mu \mathrm{l}$ RB buffer and $4 \mu \mathrm{l} \beta$ mercaptoethanol and the cells are resuspended again. After that the mixture is homogenized, incubate at room temperature for 5 minutes. Add $400 \mu \mathrm{l}$ with $70 \%$ ethanol prepared in $\mathrm{ddH}_{2} \mathrm{O}$ (DNaseRNAse free water). Shaken strongly until the mixture is homogeneous. Prepare a $2 \mathrm{~mL}$ $\mathrm{RB}$ tube column, transfer $500 \mu \mathrm{l}$ mixture to the $\mathrm{RB}$ column. Centrifuge with the strength of 14-16,000 rpm for 1 minute, then the filtrate is removed. Move the remaining mixture in the same RB column, centrifuge with a strength of $14-16,000 \mathrm{rpm}$ for 1 minute. Discard the filtrate and place the RB column in the new $2 \mathrm{~mL}$ tube ${ }^{6}$.

\section{b. Cell Washing Stage}

Added $400 \mu \mathrm{l}$ WI buffer to the RB column, centrifuge with a strength of $14-16.000 \mathrm{rpm}$ for 30 seconds. The filtrate is removed, then add $600 \mu \mathrm{L}$ of washing buffer (make sure ethanol has been added) into the RB column. Centrifuge with the strength of 14-16.000 rpm for 30 seconds, then the filtrate is removed. Place the RB column again in a $2 \mathrm{~mL}$ tube and centrifuge with a strength of 14$16.000 \mathrm{rpm}$ for 3 minutes to dry the column matrix ${ }^{6}$.

\section{c. RNA Elution Stage}

The dried RB column is placed into a new $1,5 \mathrm{~mL}$ microsentrifuge tube. Add $50 \mu$ of water-free RNase to the center of the matrix column. Let stand for 1 minute to ensure RNase is free of water absorbed. Then centrifuge with a strength of 14-16.000 rpm for 1 minute to elute purified RNA. Calculate the concentration of RNA produced $^{6}$.

\section{Manufacture of cDNA}

The total RNA used $2000 \mathrm{ng}$ was then added DNaseRNase free water to a total volume of $12 \mu \mathrm{L}$. A total of $8 \mu \mathrm{L}$ of mixed solution (5x RT-buffer $4 \mu \mathrm{L}$; random primary $1 \mu \mathrm{L}$; dNTP $2 \mu \mathrm{L}$; ReverTra-Ace $1 \mu \mathrm{L}$ ) were added to each microtube containing RNA, then resuspended and performed PCR under $30^{\circ} \mathrm{C}$ for 10 minutes, $42^{\circ} \mathrm{C}$ for 60 minutes, and $99^{\circ} \mathrm{C}$ for 5 minutes. The concentration of PCD products made from cDNA was measured using a Nanodrop device ${ }^{7}$.

Analysis Gene Expression of iNOS, TNF- $\alpha$, IL-6, IL$1 \beta, C O X-2$, and $\beta$-actin

The expression of iNOS, TNF- $\alpha$, IL-6, IL-1 $\beta$, COX-2 and $\beta$-actin genes was examined by taking $100 \mathrm{ng} / \mu \mathrm{LcDNA}$ added to $25 \mu \mathrm{L}$ PCR Master Mix (GoTaq ${ }^{\circledR}$ Green $12,5 \mu \mathrm{L}$; primary forward $1 \mu \mathrm{L}$; reverse primer $1 \mu \mathrm{L}$; DNase RNase free water $9,5 \mu \mathrm{L}$ ).

Table 1: Primary Sequens

\begin{tabular}{|c|c|c|c|c|}
\hline Gen & & Primer Sequens & Size (bp) & Annealing Temp $\left({ }^{\circ} \mathbf{C}\right)$ \\
\hline iNOS & $\begin{array}{l}\mathrm{F} \\
\mathrm{R}\end{array}$ & $\begin{array}{l}\text { 5'-CGAAACGCTTCACTTCCAA-3' } \\
\text { 5'-TGAGCCTATATTGCTGTGGCT-3' }\end{array}$ & 311 & 60 \\
\hline IL-1 $\beta$ & $\begin{array}{l}\mathrm{F} \\
\mathrm{R}\end{array}$ & $\begin{array}{l}\text { 5'-CCCTGCAGCTGGAGAGTGTGGA-3' } \\
\text { 5'-TGTGCTCTGCTTGTGAGGTGCTG-3' }\end{array}$ & 447 & 62,5 \\
\hline TNF- $\alpha$ & $\begin{array}{l}\mathrm{F} \\
\mathrm{R}\end{array}$ & $\begin{array}{l}\text { 5'-TGTGCCGCCGCTGTCTGCTTCACGCT-3' } \\
\text { 5'-GATGAGGAAAGACACCTGGCTGTAGA-3' }\end{array}$ & 374 & 55 \\
\hline IL-6 & $\begin{array}{l}\mathrm{F} \\
\mathrm{R}\end{array}$ & $\begin{array}{l}\text { 5'-GATGCTACCAAACTGGATATAATC-3' } \\
\text { 5'-GGTCCTTAGCCACTCCTTCTGTG-3' }\end{array}$ & 269 & 55 \\
\hline COX-2 & $\begin{array}{l}\mathrm{F} \\
\mathrm{R}\end{array}$ & $\begin{array}{l}\text { 5'- CCTGTGTTCCACCAGGAGT-3' } \\
\text { 5'- GTCCCTGGCTAGTGCTTCAG-3' }\end{array}$ & 249 & 58 \\
\hline$\beta$-actin & $\begin{array}{l}\mathrm{F} \\
\mathrm{R}\end{array}$ & $\begin{array}{l}\text { 5'-TGGAATCCTGTGGCATCCATGAAAC-3', } \\
\text { 5'-TAAAACGCAGCTCAGTAACAGTCCG-3' }\end{array}$ & 349 & 55 \\
\hline
\end{tabular}

PCR consists of 35 amplification cycles and each cycle is carried out for 30 seconds at $95^{\circ} \mathrm{C}$ (denaturation), 1 minute at annealing temperature $\left(55^{\circ} \mathrm{C}\right.$ for TNF- $\alpha$, IL- 6 , COX $-258^{\circ} \mathrm{C}, \beta$-actin and $60^{\circ} \mathrm{C}$ for iNOS) and 45 seconds at $95^{\circ} \mathrm{C}$ (denaturation), 1 minute at annealing temperature $62,5^{\circ} \mathrm{C}$ for IL-1 $\beta$.) And 1 minute at $72^{\circ} \mathrm{C}$ (elongation) in a thermal cycler (ProFlexTM 3x32- well PCR System,
Applied Biosystems), $\beta$-actin is a house keeping gene that is used as an internal control to standardize the relative expression levels for all biomarkers. PCR products were analyzed by electrophoresis in $2 \%$ agarose and TrisBorate-EDTA (Vivantis), and flouroVue (Smobio) as a dye ${ }^{13,14}$. 


\section{RESULTS AND DISCUSSION}

\section{Gene Expression Test}

The results of gene expression testing in Figure 1 show that VCO can reduce the expression of TNF- $\alpha$, IL-6, COX-2, IL-1 $\beta$ and iNOS compared with LPS which experiences the greatest increase. The band image with the treatment (VCO, Dexamethasone) looks thinner compared to the treatment with LPS which produces the thickest band. LPS is the main inducer that can activate macrophages so as to increase gene expression ${ }^{10,11}$. Based on the results of the measurement of gene expression in Figure 1, it was analyzed statistically using One way ANOVA, then continued with the Post Hoc Test in the form of the Tuckey HSD test giving the result that there was a significant difference between the treatment group with cell control as normal control (untreated control), lipopolysaccharides as negative controls (can increase gene expression), and dexamethasone as positive controls (can reduce gene expression).
IL-6

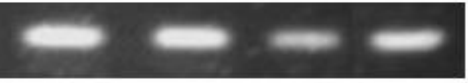

$269 \mathrm{Bp}$

$\operatorname{cox}-2$

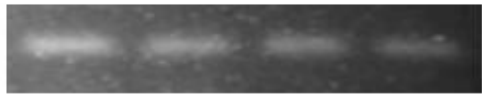

$249 \mathrm{Bp}$

TNF- $\alpha$

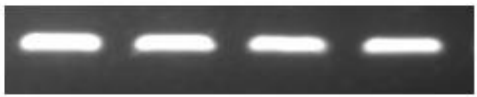

$374 \mathrm{Bp}$

IL- $1 \beta$

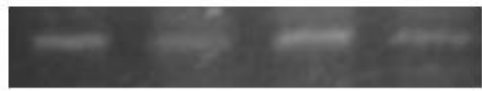

$441 \mathrm{Bp}$

iNos

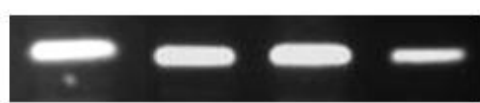

$311 \mathrm{Bp}$

B-actin

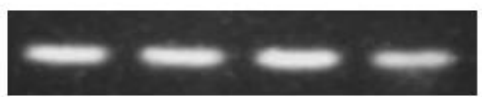

$349 \mathrm{Bp}$

$$
\text { a } \quad b \quad c \quad d
$$

Figure: 1 Effect of TNF- $\alpha$, IL-6, IL-1 $\beta$, COX-2 and iNOS gene expression on VCO, a. Cell Control; b. Lipopolisakarida; c. VCO 25 $\mu \mathrm{g} / \mathrm{mL}$; d. Dexamethasone $2,5 \mu \mathrm{g} / \mathrm{mL}$,

The effect of TNF- $\alpha$, IL-6, IL-1 $\beta$, COX-2, iNOS given (VCO) gene expression was significantly different $p<0,05$ seen in Table 2.

Table 2: Effect of gene expression density of VCO

\begin{tabular}{|c|c|c|c|}
\hline NO & Genes & Treatment Group & Average Density \pm SEM \\
\hline \multirow[t]{4}{*}{1.} & TNF- $\alpha$ & VCO & $0,91 \pm 0,010^{\mathrm{abc}}$ \\
\hline & $\bar{r}$ & Dexamethasone & $0,70 \pm 0,010^{\mathrm{ab}}$ \\
\hline & 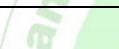 & LPS & $1,18 \pm 0,010^{\mathrm{ac}}$ \\
\hline & $(0)$ & KS & $1,00 \pm 0,000^{\mathrm{bc}}$ \\
\hline \multirow[t]{4}{*}{2.} & IL-6 & $\mathrm{VCO}$ & $1,23 \pm 0,015^{\text {abc }}$ \\
\hline & 4 & Dexamethasone & $0,87 \pm 0,015^{\mathrm{ab}}$ \\
\hline & & LPS & $1,16 \pm 0,010^{\mathrm{ac}}$ \\
\hline & 10 & KS & $1,00 \pm 0,000^{\mathrm{bc}}$ \\
\hline \multirow[t]{4}{*}{3.} & IL-1 $\beta$ & VCO & $2,47 \pm 0,010^{\mathrm{ac}}$ \\
\hline & & Dexamethasone & $1,70 \pm 0,010^{\mathrm{abc}}$ \\
\hline & & LPS & $3,38 \pm 0,010^{\mathrm{ac}}$ \\
\hline & & KS & $1,00 \pm 0,000^{\mathrm{bc}}$ \\
\hline \multirow[t]{4}{*}{4.} & COX-2 & VCO & $1,02 \pm 0,015^{\mathrm{abc}}$ \\
\hline & & Dexamethasone & $0,77 \pm 0,010^{\mathrm{ab}}$ \\
\hline & & LPS & $1,22 \pm 0,015^{\mathrm{c}}$ \\
\hline & & KS & $1,00 \pm 0,000^{\mathrm{bc}}$ \\
\hline \multirow[t]{4}{*}{5.} & iNOS & VCO & $0,90 \pm 0,015^{\mathrm{abc}}$ \\
\hline & & Dexamethasone & $0,47 \pm 0,015^{\mathrm{ab}}$ \\
\hline & & LPS & $1,49 \pm 0,015^{\mathrm{c}}$ \\
\hline & & KS & $1,00 \pm 0,000^{\mathrm{c}}$ \\
\hline
\end{tabular}

a: Sig $(\mathrm{P})<0,05$ there is a significant difference with the normal control group (KS), b: Sig $(\mathrm{P})<0,05$ there is a significant difference with the negative control group (LPS), c: Sig $(\mathrm{P})<0,05$ there is a significant difference with the positive control group (dexamethasone)

VCO administration can reduce TNF- $\alpha$, iNOS, IL- $1 \beta$, COX-2 and IL-6 expression in Lipopolysaccharideinduced RAW cells. In iNOS expression, VCO density values $(0,90 \pm 0,015)$ showed significantly different effects with positive and negative controls $p<0,05$, VCO IL- $1 \beta$ density values $(2,47 \pm 0,010)$ showed different effects. significant with normal control, positive control and negative control $\mathrm{p}<0,05$, TNF- $\alpha$ density value on VCO $(0,91 \pm 0,010)$ showed significantly different effects from positive control and negative control $\mathrm{p}<0,05$, then the value IL-6 density at VCO $(1,23 \pm 0,015)$ showed significantly different effects from normal and positive 
controls $\mathrm{p}<0,05$, and $\mathrm{COX}-2$ density values at $\mathrm{VCO}$ $(1,02 \pm 0,015)$ showed significantly different effects with normal and positive controls $\mathrm{p}<0,05$.
The effect of gene expression density can be seen in Figure. 2 shows that the graph has decreased significantly compared to LPS.

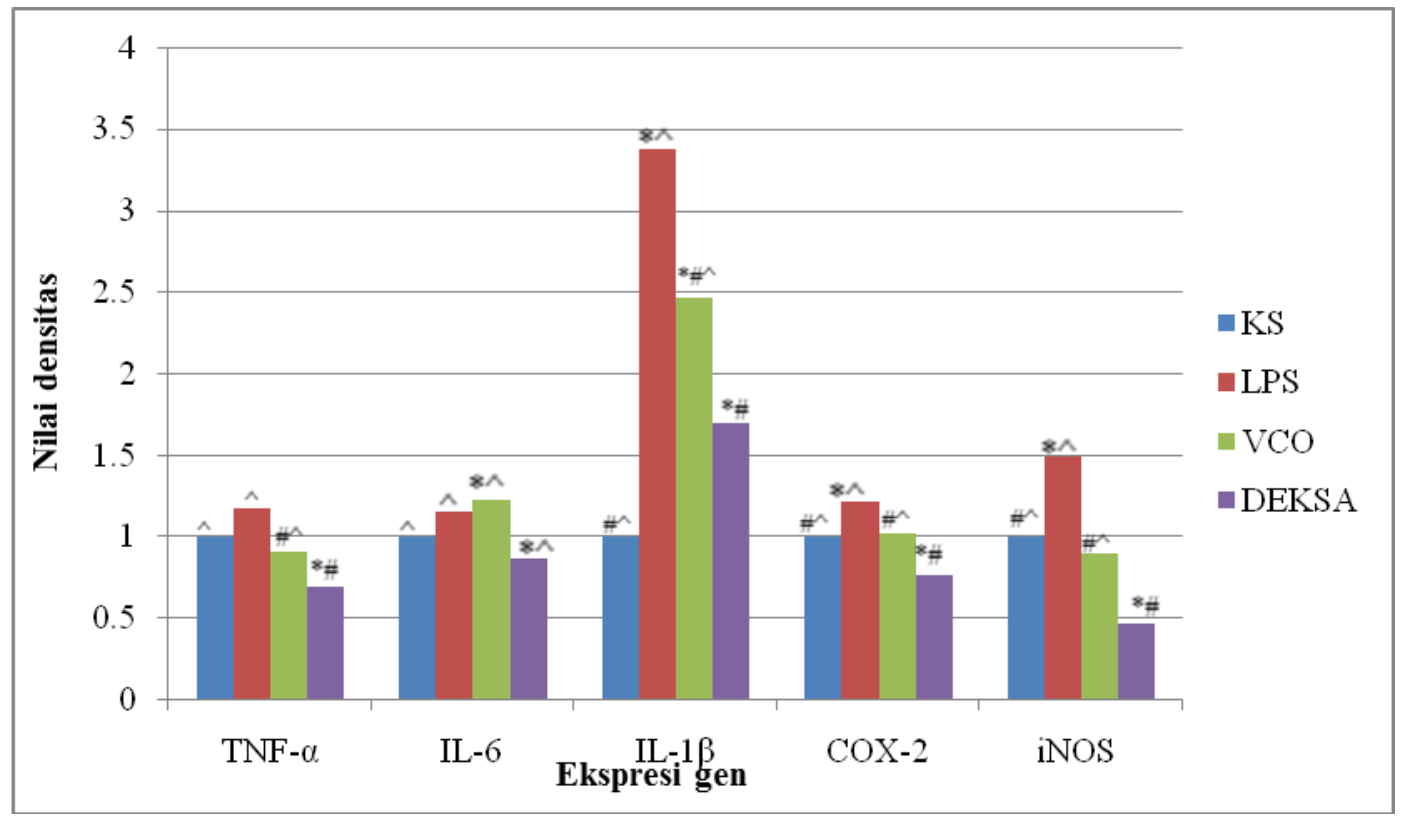

Figure 2 Graphic Effect of TNF- $\alpha$, IL-6, IL-1 $\beta$, COX-2 and iNOS gene expression on VCO. * $p<0,05$ significantly different from the normal control group (KS) \#p<0,05 significantly different from the negative control group (LPS). ${ }^{\wedge} \mathrm{p}<0.05$ significantly different from the positive control group (dexamethasone).

In TNF- $\alpha$, IL-6, IL-1 $\beta$, COX-2, and iNOS genes with $\mathrm{VCO}$, the decrease was greater than VCO. TNF- $\alpha$, IL-6, IL-1 $\beta$, COX-2 can be produced from macrophages in response to bacterial LPS stimuli, infections and inflammatory stimuli. These cytokines also play an important role in the immune system by helping cytotoxic and cytostatic effects on infected cells or malignant cells.

\section{CONCLUSION}

Based on the results of the research the administration of VCO can reduce the density value of TNF- $\alpha$, iNOS, IL$1 \beta$, COX-2 and IL-6 on RAW 264.7 cells induced by lipopolysaccharides.

\section{ACKNOWLEDGEMENT:}

The authors are grateful to the USU Pharmacognition Laboratory and the UGM Parasitology Laboratory for assisting the author in completing this research.

\section{REFERENCES}

1. Agita, A. danThaha, M. (2017). Inflamation, Immunity and Hypertension. Acta Med Indonesia.2017; 159-161.

2. Chung, H.Y., Kim, H.J., Kim, K.W., Choi, J.S. and Yu BP. Molecular inflammation hypothesis of aging based on the anti-aging mechanism of calorie restriction. Microsc Res Tech.2002; 59: 264272

3. Dayrit, F.M., Buenafe, O.E.M., Chainani, E.T., de Vera, I.M.S., Dimzon, I.K.D., Gonzales, E.G., Santos, J.E.R. et al (2007) Standards for essential composition and quality factors of commercial virgin coconut oil and its differentiation from RBD [refined bleached and deodorized]. Philipp. J. Sci. Philipp.

4. Laveti, D., Kumar, M., Hemalatha, R., Sistla, R., Naidu, V. G., Talla, V., Nagpal, R., et al. Anti-inflammatory Treatments For Chronic Diseases: A review. Inflammation \& Allergy Drug Targets, 2013; 12(5).349-361.

5. Man, Y.B.C. dan Manaf, M.A. Medium-Chain Triacylglycerols. In book Nutraceutical and Specialty Lipids and their Co-Products.
Editor: Shahidi, F. USA: Taylor \& Francis Group, LLC. Halaman: 2006; 31-32.

6. Novycha. A., Rosidah.,Yuandani., Suryani. S., and Satria.D.The Immunomodulatory Activities of PicriaFel-TerraeLour Herbs towards RAW 264.7 Cells.Journal of Medical Science. 2019; 7(1): 24-28.

7. Hadiarto, T., Listanto, E., Eny, I. and Riyanti. Identification of $R B$ gene cDNA in Genetically Modified Potato Katahdin SP951.Jurnal AgroBiogen. 2015; 11(2): 59-64.

8. Silalahi, J and Surbakti, C. Burn Wound Healing Activity of Hydrolyzed Virgin Coconut Oil. USA. IJPRIF.2015; 8(1):67-73.

9. Sumiwi, A.S., Ramadhani, N. (2015). Antiinflammatory Activity of Various Plants Allegedly Derived from Flavonoids. Padjadjaran University Faculty of Pharmacy.Farmaka 2015; 14(2):112.

10. Yu, G. J., Choi, I. W., Kim, G. Y., Kim, B. W., Park, C., Hong, S. H., et al. Anti-inflammatory potential of saponins derived from cultured wild ginseng roots in lipopolysaccharide-stimulated RAW 264.7 macrophages. International journal of molecular medicine, 2015; 35(6): 1690-1698.

11. Kim, G.T., Tran, N.K.S., Choi, E.H., Song, Y.J., Song, J.H, Shim S.M. et al. Immunomodulatory Efficacy of Standardized Annonamuricata (Graviola) Leaf Extract via Activation of MitogenActivated Protein Kinase Pathways in RAW 264.7 Macrophages.Evidence-Based Complementary and Alternative Medicine:2016; 1-10.

12. Lawrence, T. and Fong, C. (2010). The Resolution of Inflammation: Anti-Inflammatory Roles for NF kappa B. The International Journal of Biochem-istry \& Cell Biology, 2010; 42(4), 519-523.

13. Yanti., Pramudito., E.T., Nuriasari. N. and Juliana.K. (2011).Lemon Pepper Fruit Extract (Zanthoxylumacanthopodium DC.) Suppresses the Expression of Inflammatory Mediators in LipopolysaccharideInduced Macrophages In Vitro.American Journal of Biochemistry and Biotechnology.2010; 7(4):190-195.

14. Kim, G.T., Tran, N.K.S., Choi, E.H., Song, Y.J., Song, J.H, Shim, S.M. et al. Immunomodulatory Efficacy of Standardized Annonamuricata(Graviola) Leaf Extract via Activation of MitogenActivated Protein Kinase Pathways in RAW 264.7 Macrophages.Evidence-Based Complementary and Alternative Medicine: 2016; 1-10. 